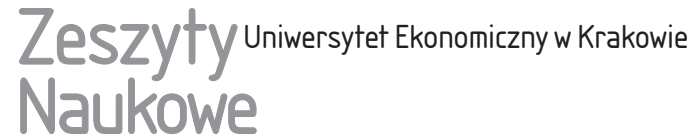

\author{
Piotr Gryszel
}

\section{Ekonomia doświadczeń w kształtowaniu konkurencyjności regionów turystycznych}

\section{Streszczenie}

Współczesne atrakcje działające na zasadzie mcdonaldyzacji i mcdisneyizacji oferty turystycznej są pozytywnie oceniane przez turystów i często stanowią główny powód podjęcia podróży, przyczyniając się do znacznego podniesienia konkurencyjności turystycznej obszaru. Celem artykułu jest ocena wpływu współczesnych atrakcji turystycznych kreujących doświadczenia turystów na konkurencyjność regionu turystycznego. W artykule wykorzystano studia literaturowe oraz badania opinii turystów odwiedzających Sudety jako region turystyczny. Analizie poddano oceny, wpisy i opinie wyrażane w aplikacji TripAdvisor, odnoszące się do atrakcji turystycznych zlokalizowanych w badanym regionie turystycznym. Należy podkreślić, że współczesne podejście związane z gospodarką doświadczeń jest jednym z najbardziej skutecznych narzędzi kreujących pozycję konkurencyjną regionu na rynku turystycznym.

Słowa kluczowe: konkurencyjność, region turystyczny, ekonomia doświadczeń, atrakcja turystyczna.

Klasyfikacja JEL: L83, M31, A12.

Piotr Gryszel, Uniwersytet Ekonomiczny we Wrocławiu, Wydział Ekonomii, Zarządzania i Turystyki w Jeleniej Górze, Katedra Marketingu i Zarządzania Gospodarką Turystyczną, ul. Nowowiejska 3, 58-500 Jelenia Góra, e-mail: piotr.gryszel@ue.wroc.pl 


\section{Wprowadzenie}

Zachodzące procesy globalizacyjne i integracja gospodarek zmuszają przedsiębiorstwa i regiony turystyczne do stałego podnoszenia swej konkurencyjności rynkowej. W czasach systematycznie zwiększającego się konsumpcjonizmu, aby skutecznie kształtować swą przewagę konkurencyjną na rynku, coraz ważniejsza staje się innowacyjność produktowa i procesowa. Kolejnym etapem w rozwoju gospodarki po gospodarce agrarnej, epoce przemysłu i gospodarce usług - jak się wydaje - będzie ekonomia (gospodarka) doświadczeń (experience economy). Proces ten, na który w 1998 r. uwagę zwrócili J. Pine i J. Gilmore, jest efektem progresji wartości ekonomicznej. Ekonomia doznań to nowy sposób myślenia na temat łączenia się z klientami i zapewnienia ich lojalności (Majchrzak 2014). Ekonomia doświadczeń ma też szczególne znaczenie w procesie tworzenia i rozwoju atrakcji turystycznych i regionalnej oferty turystycznej. Wiele na ten temat pisali m.in. B. Marciszewska (2010), A. Stasiak (2013a, b), Ł. Iwasiński (2015). Najważniejszymi czynnikami mającymi wpływ na podnoszenie konkurencyjności regionów turystycznych i tworzenie produktu turystycznego obszaru są m.in. walory i atrakcje turystyczne. Należy wymienić również infrastrukturę turystyczną i ogólną oraz czynniki związane z przedsiębiorczością i jakością życia mieszkańców.

W opracowaniach z zakresu geografii turystycznej częściej używane jest pojęcie waloru turystycznego jako elementu środowiska naturalnego i antropologicznego stanowiącego przedmiot zainteresowania turystów i decydującego o atrakcyjności turystycznej miejsca lub obszaru (Kowalczyk 2000, s. 88; Lijewski, Mikułowski i Wyrzykowski 2002, s. 16; Jędrusik, Makowski i Plit 2010, s. 15). W opracowaniach ekonomicznych używa się coraz częściej pojęcia atrakcji turystycznej jako miejsca, wydarzenia lub obiektu mającego zdolność przyciągania turystów i decydującego o tym, że wybierają oni dany obszar (Middleton 1996, s. 89; Swarbrooke 2002; Kruczek 2011; Nowacki 2012; Kruczek 2017). Z perspektywy kształtowania konkurencyjności regionu lub miejscowości turystycznej definicja atrakcji turystycznej jest bardziej przydatna.

Celem artykułu jest ocena wpływu współczesnych atrakcji turystycznych kreujących doświadczenia turystów na konkurencyjność regionu turystycznego. Hipoteza, którą autor chce zweryfikować, opiera się na stwierdzeniu, że atrakcje turystyczne mogą być skutecznie wykorzystywane do kreowania unikalnych doświadczeń turystów i tym samym poprawiania konkurencyjności regionu na co najmniej krajowym rynku turystycznym. Jako obszar badawczy wybrano atrakcje turystyczne zlokalizowane w Sudetach. 


\section{Ekonomia doświadczeń we współczesnej turystyce}

Zmiany na współczesnym rynku turystycznym polegają na przechodzeniu od modelu masowej turystyki 3S (sea, sand, sun, czyli morze, piasek, słońce) do modelu „kreatywnej” turystyki 3E (entertainment, excitement, education, czyli rozrywka, fascynacja, edukacja) (Kowalczyk 2014). Można mieć jednak pewne wątpliwości co do takiego przekonania, gdyż model turystyki 3E od dawna funkcjonował obok modelu turystyki 3S. Zawsze byli turyści preferujący bierne formy wypoczynku i turyści kreatywnie uprawiający turystykę. Obecnie mogą tylko zmienić się proporcje; oprócz modelu turystyki 3E będzie funkcjonował model turystyki 3S. Do klasycznego modelu 3E dodać należy jeszcze czwarte E, engagement, czyli zaangażowanie ${ }^{1}$. Zamiast biernego spędzania czasu wolnego turysta poszukuje przeżyć. Po okresie zauroczenia biernym wypoczynkiem polegającym głównie na plażowaniu obecnie turyści coraz częściej przygotowują się do podróży teoretycznie i praktycznie. Obserwuje się renesans zainteresowania historią, kulturą, codziennym życiem mieszkańców danego regionu lub kraju. D. MacCannell (2005, s. 150-153) twierdzi, że istotą nowoczesnej turystyki jest poszukiwanie autentyczności, którą utraciliśmy w naszym sztucznym, wyobcowanym świecie. Aby podkreślić zmiany zachodzące we współczesnej turystyce oraz to, że nie ma ona wiele wspólnego z dawną turystyką polegającą tylko na podróżowaniu dla samego podróżowania i zwiedzaniu dla samego zwiedzania, często mówi się o postturystyce, która ma na celu m.in. poszukiwanie autentyczności przeżyć (Cohen 2011, Żemła 2017).

Pewnym przeciwstawieniem dla powyższej tezy może być przedstawiona przez K. Podemskiego (2004, s. 94-97) koncepcja G. Ritzera, który opisuje zjawiska mcdonaldyzacji i mcdisneyizacji współczesnej turystyki. Twierdzi on, że współczesny przemysł turystyczny przybiera postać swoistego turystycznego fast foodu, czyli fabryki doznań, która ma obsłużyć turystów szybko, łatwo i przyjemnie zgodnie z przyjętymi standardami, czyli z pomięciem autentyczności opisywanej przez D. MacCannella. Natomiast mcdisneyizacja turystyki powoduje, że poszczególne atrakcje turystyczne traktowane są jako szczególne „świątynie konsumpcji”, w których następuje pospieszna, pozbawiona głębszej refleksji, konsumpcja. Największe nasilenie komercjalizacji miejsc dotyczy sytuacji, w których za atrakcje turystyczne uznaje się obiekty niemające żadnego związku z danym miejscem lub regionem, np. gabinety figur woskowych, „,domy do góry nogami”, parki dinozaurów, parki rozrywki, czy wielkie centra handlowe, a więc miejsca

${ }^{1}$ Często elementem oferty turystycznej stają się gry fabularne i miejskie, LARP (live action role-playing) jako szczególny rodzaj gry fabularnej, questing, geocaching, czy gry typu Pokémon Go. 
zaprojektowane w celu osiągania korzyści. Wiele tego typu atrakcji turystycznych można określić mianem pułapek turystycznych (Kruczek 2011, s. 28-44).

Pojawia się zatem wspomniany przez K. Podemskiego (2004, s. 97) dylemat, czy to turyści, szukając autentyzmu i określonych przeżyć, padają ofiarą manipulacji przemysłu turystycznego, czy też to właśnie przemysł turystyczny dopasowuje się do oczekiwań turystów i sprzedaje im fałszywe doznania i nierzetelną ofertę turystyczną.

Doświadczenia jednak, abstrahując od ich autentyczności, stanowią element składowy współczesnego produktu turystycznego tak w ujęciu wąskim, jak i w ujęciu szerokim, czyli regionalnym. W najpopularniejszych ujęciach definicji szeroko rozumianego produktu turystycznego obszaru znaleźć można odniesienie do doświadczeń turystów. V.T.C. Middleton mówi o pakiecie składników materialnych i niematerialnych, opartych na możliwościach spędzania czasu w miejscu docelowym. Pakiet jest postrzegany przez turystę jako przeżycie dostępne za określoną cenę (Middleton 1996, s. 89). Podobnie produkt turystyczny definiują J. Kaczmarek, A. Stasiak i B. Włodarczyk (2010, s. 75), zdaniem których produkt turystyczny to zbiór użyteczności związanych z podróżami turystycznymi, czyli dostępne na rynku dobra i usługi turystyczne umożliwiające planowanie podróży, ich odbywanie, przeżywanie oraz gromadzenie doświadczeń z nimi związanych. D. MacCannell (2002, s. 33) ponadto uważa, że w turystyce coraz częściej wytwarza się i sprzedaje czyste doświadczenie, które nie pozostawia śladów materialnych.

W dobie globalizacji i rosnącej konkurencji rynkowej obszary turystyczne poszukują coraz nowszych metod poprawy swej konkurencyjności rynkowej. Na poziomie rdzenia produktu konkurencja jest raczej mało efektywna, ponieważ trudno jest zmienić naturalne zasoby obszaru. Konkurencja infrastrukturalna w dobie globalnych inwestycji też jest utrudniona. Pozostaje zatem konkurowanie na poziomie wartości dodanej, jaką w odniesieniu do regionalnego produktu może być oprócz wizerunku i marki obszaru również odpowiednie doświadczenie turysty, którego nie będzie w stanie zdobyć w innym regionie. Odpowiada to dążeniu do modelu turystyki 3E i 4E. Zatem w regionach konieczne staje się zastosowanie założeń gospodarki opartej na doświadczeniach. Jako główne można wymienić założenia zawarte w stwierdzeniach (Dziewianowska 2013):

- konsumenci nabywają nie produkty czy usługi, lecz towarzyszące im doznania,

- przedsiębiorstwa odwołują się do uczuć i zmysłów, a nie wyłącznie do czystej logiki i racjonalizmu nabywców,

- efektywność działania przestała być uważana za najważniejszy miernik sukcesu, 
- konsumenci są traktowani jako porozumiewające się między sobą jednostki zdolne do samostanowienia i tworzące społeczności wokół wspólnych wartości.

Element doświadczenia może zatem istotnie podnieść wartość produktu, a wartość doświadczenia może być narzędziem strategicznym przedsiębiorstwa lub obszaru podobnym do marketingu. Dlatego też warto kształtować emocje i doświadczenia klientów. Jedną z dróg do tego prowadzących jest zaangażowanie konsumenta w etap projektowania dobra i usługi, co jest coraz częściej stosowane także w polskich przedsiębiorstwach, które już w tym dostrzegły jedno ze źródeł przewagi konkurencyjnej (Majchrzak 2014). J. Pine i J. Gilmore (1998) za doświadczenie uznają wynikający z kontaktów klienta z firmą ciąg wydarzeń angażujących go na poziomie uczuciowym, fizycznym, intelektualnym, a nawet duchowym. Zdaniem B. Marciszewskiej (2010, s. 13-14) doświadczenia jako nowe źródło wartości nie powstają w izolacji od trzech rozpoznawalnych na rynku rodzajów produktów: surowców, towarów i usług. Ich ekonomiczny potencjał założony i wytworzony w procesie produkcji - uaktywnia się wraz z rozpoczęciem konsumpcji, a doświadczenie jawi się jako dodatkowe źródło wartości tworzonej w jednoczesnym procesie produkcji i konsumpcji usług. W przypadku regionu turystycznego odpowiednikiem surowców mogą być walory turystyczne, towarów - infrastruktura turystyczna (w tym przedsiębiorstwa turystyczne), a usług - proces obsługi turystów.

Ekonomia doświadczeń, w której doświadczenia występują jako specyficzny produkt, może być zatem określona jako aktywność ludzka, w której sprzedający (kreujący doświadczenia) oferują na rynku doświadczenia utrwalające się w pamięci konsumentów pod postacią indywidualnych (osobistych) doznań i wrażeń dostarczanych dzięki ekonomicznej funkcji kreowania (stage) (Marciszewska 2010, s. 15).

A. Stasiak (2013a) do najważniejszych sposobów intensyfikacji wrażeń i emocji turystów zalicza:

- przekształcanie infrastruktury turystycznej w unikatowe atrakcje turystyczne,

- wzbogacanie starych form produktu turystycznego o elementy doświadczeń i emocji,

- kreowanie tzw. rozszerzonej rzeczywistości,

- nowe formy zapisywania doświadczeń turystycznych i dzielenia się nimi,

- odkrywanie nowych przestrzeni turystycznych, które mają zapewnić niepowtarzalne przeżycia, a czasami wręcz ekstremalne doznania,

- rozwój nowych form turystyki dostarczających oryginalnych, ponadprzeciętnych emocji, a także rozwijających umiejętności, kreatywność i osobowość turysty. 


\section{Konkurencyjność regionów turystycznych}

W konsekwencji zmiany paradygmatu rozwoju regionalnego w latach 90 . XX w. regiony musiały odpowiedzieć na kluczowe pytanie, jak skutecznie budować swoją konkurencyjność i zwiększyć atrakcyjność dla potencjalnych inwestorów, tworząc tym samym warunki do dynamizowania rozwoju, zwłaszcza tzw. inteligentnego (smart growth), opartego na innowacyjnych produktach i usługach generujących wysoką wartość dodaną. W związku z tym konkurencyjność stała się podstawą, na której są konstruowane regionalne strategie rozwoju. Kreowanie konkurencyjnych regionów jest bardzo trudne m.in. dlatego, że model rozwoju stale ewoluuje i kryteria lokalizacji ulegają zmianom. Regiony w związku z tym są zobligowane do podejmowania nowych działań restrukturyzacyjnych polegających na zastępowaniu nowymi elementami tych części struktury regionu (gospodarki lub infrastruktury), które są nieprzystosowane do obecnych i przyszłych czynników lokalizacji i negatywnie ważą na atrakcyjności danego regionu dla potencjalnych inwestorów. Regiony muszą antycypować lub przynajmniej nadążać za pojawiającymi się wymogami i trendami nieprzerwanie ewoluującej gospodarki (Łaźniewska 2013, s. 28).

Poddając szczegółowej analizie problematykę regionalnej konkurencyjności, można stwierdzić, że regionalna konkurencyjność może być określana jako trwała zdolność regionu do konkurowania z innymi regionami, do zapewnienia trwałego ekonomicznego wzrostu i rozwoju, z możliwością przyciągania i utrzymania produktywnego kapitału, kreatywnych talentów, jak również bycia innowacyjnym w szerokim sensie tego słowa (Konkurencyjność... 2012, s. 42). Bardzo ważne jest to, że regionalna konkurencyjność nie korzysta z eksploatacji zasobów, ale zakłada identyfikację wzrostowych potencjałów i ograniczeń obszaru, jak również wzmocnienie jego unikatowej kombinacji zasobów (innowacyjności i kreatywności, wiedzy technologii, historycznych i kulturowych uwarunkowań tolerancji, sieci społecznych, zaufania, odpowiedzialności itd.), ażeby stworzyć korzystne warunki życia i pracy. Regionalna konkurencyjność to innowacyjne i przedsiębiorcze przekształcenie tych zasobów w intelektualny kapitał, wartość dodaną, ekonomiczny wzrost i rozwój (Łaźniewska 2013, s. 26-27).

Złożony charakter konkurencyjności regionów zauważyli również badacze opisujący regiony turystyczne G.I. Crouch i J.R.B. Ritchie (1999, s. 137-152) oraz L. Dwyer i C. Kim (2003, s. 396-414). Dwaj pierwsi zaproponowali też jedną z najpopularniejszych definicji konkurencyjności regionów turystycznych. Ich zdaniem tym, co decyduje o konkurencyjności regionu turystycznego, jest jego zdolność do zwiększania wydatków turystycznych (m.in. inwestycyjnych), aby w coraz większym stopniu przyciągać gości, zapewniając im satysfakcjonujące, niezapomniane przeżycia, w opłacalny sposób, przy jednoczesnym zwiększeniu 
dobrobytu mieszkańców i zachowaniu zasobów naturalnych dla przyszłych pokoleń (Mazanec, Wöber i Zins 2007, s. 86-95). Konkurencyjność regionów turystycznych zatem powinna być rozpatrywana w ujęciu systemowym - jako system połączonych ze sobą różnych elementów. Na konkurencyjność tę wpływa bowiem wiele różnych czynników natury tak obiektywnej, jak i subiektywnej. System ten można przedstawić w postaci modeli.

Pierwszym modelem konkurencyjności regionów turystycznych był zaprezentowany przez G.I. Croucha i J.R.B. Ritchiego w 1992 r. tzw. calgarski model konkurencyjności regionów turystycznych opierający się na pięciu filarach konkurencyjności turystycznej, tj. czynnikach atrakcyjności turystycznej, zarządzaniu regionem turystycznym, modelu organizacyjnym regionu turystycznego, systemie informacyjnym oraz efektywności działań. Model ten potem ewoluował (Šmardová 2012, s. 133). Najbardziej znane i najczęściej przytaczane modele zaproponowali jednak G.I. Crouch i J.R.B. Ritchie (1999, s. 137-152) oraz L. Dwyer i C. Kim (2003, s. 396-414). Pierwszy model prezentuje 37 czynników podzielonych na 5 grup obejmujących czynniki i zasoby wspomagające, czynniki i zasoby przyciągające, zarządzanie regionem turystycznym, politykę, planowanie i zagospodarowanie oraz czynniki wzmacniające i doskonalące. Wszystko to powinno uwzględniać czynniki makrootoczenia i mikrootoczenia oraz przewagę konkurencyjną i przewagę komparatywną (Ritchie i Crouch 2005, s. 63).

Drugi model opiera się na 5 grupach czynników obejmujących zasoby odziedziczone i wytworzone, zasoby i czynniki wspierające, zarządzanie regionem turystycznym oraz uwarunkowania popytu (Dwyer i Kim 2003, s. 396-414). Szerzej na temat konkurencyjności regionów turystycznych autor wspominał w swych wcześniejszych pracach (Gryszel 2014a, b, c, 2015, Gryszel i Walesiak 2018), tam też zostały przedstawione modele konkurencyjności regionów turystycznych i została zaproponowana syntetyczna miara konkurencyjności regionu turystycznego (SMKRT). Stosując stworzoną przez M. Walesiaka (2011) uogólnioną miarę odległości GDM, P. Gryszel i M. Walesiak (2018) opracowali ranking konkurencyjności turystycznej gmin sudeckich oraz wyodrębnili 4 klasy gmin o podobnej konkurencyjności turystycznej ${ }^{2}$. W pierwszej klasie gmin o bardzo podobnym charakterze i wysokiej konkurencyjności turystycznej znalazły się gminy: Karpacz, Szklarska Poręba, Świeradów-Zdrój, Kudowa-Zdrój, Polanica-Zdrój i Szczawno-Zdrój, które wchodzą w skład dwóch największych ośrodków turystycznych Sudetów, oraz 4 gminy uzdrowiskowe. Można zatem domniemywać, że występowanie walorów uzdrowiskowych na terenie gminy determinuje takie działania władz gminnych i podmiotów gospodarczych, które kształtują wysoką pozycję konkurencyjną tego typu jednostek samorządu terytorialnego. Z racji

${ }^{2}$ Szczegółowy opis sposobu doboru gmin do badania i wyodrębniania klas konkurencyjności znajduje się w pracy (Gryszel i Walesiak 2018). 
ograniczeń ustawowych w prowadzeniu innych rodzajów działalności gospodarczej, gminy te są wręcz skazane na rozwój funkcji turystycznej. Muszą zatem dbać o konkurencyjność turystyczną, gdyż rozwój turystyki jest podstawą poziomu i jakości życia mieszkańców tych gmin. Turystyka w gminie ma charakter polaryzacyjny, co oznacza, że determinuje rozwój gminy i ma znaczenie dominujące. Takie miejscowości i regiony o znacznie rozwiniętej funkcji turystycznej będą brane pod uwagę w badaniach wpływu atrakcji turystycznych na ich konkurencyjność turystyczną.

W klasie trzeciej o niskiej konkurencyjności turystycznej znalazło się 7 gmin miejskich, tj. Kamienna Góra, Lubań, Bielawa, Dzierżoniów, Kłodzko, Nowa Ruda i Wałbrzych. Są to największe miasta sudeckie. Ze względu na liczbę mieszkańców w tych miastach i konieczność zapewnienia miejsc pracy w zdywersyfikowanej gospodarce funkcja turystyczna w tego typu gminach ma charakter neutralny i nie wywiera istotnego wpływu na rozwój obszaru, ma tylko znaczenie uzupełniające. W tym przypadku są to miejscowości o mocno zróżnicowanej strukturze funkcjonalnej, co prowadzi do zaniżenia poziomu konkurencyjności turystycznej. Pewnym wyjątkiem są Wałbrzych i Kłodzko pełniące obok funkcji administracyjno-gospodarczych również funkcje ośrodków rozrządowych ruchu turystycznego.

Wyróżniono ponadto osobną klasę obejmującą 5 gmin o bardzo specyficznym charakterze. Są to 3 typowe gminy uzdrowiskowe - Duszniki-Zdrój, Lądek-Zdrój i Jedlina-Zdrój - oraz Jelenia Góra i Stronie Śląskie. Gminy te posiadają wysoki poziom konkurencyjności turystycznej (miejsca 5, 9, 10, 11 i $12 \mathrm{w}$ rankingu), ale charakterystyczne cechy wyróżniają je z badanej zbiorowości. Jelenia Góra to miasto liczące ok. 80 tys. mieszkańców, o polifunkcyjnym charakterze. W 1976 r. włączono w jego granice uzdrowisko Cieplice, a także typowo turystyczne osady Sobieszów i Jagniątków. Miasto również cechuje się rozwiniętą funkcję przemysłową. Natomiast Duszniki-Zdrój położone są pomiędzy dwoma dużymi uzdrowiskami mającymi bardzo wysoką pozycję konkurencyjną, co spowodowało konieczność podjęcia funkcji przemysłowej. Jedlina-Zdrój to jedno z mniejszych uzdrowisk sudeckich, posiadające 180 miejsc uzdrowiskowych, leżące w aglomeracji wałbrzyskiej i skłaniające się ku przemysłowemu Wałbrzychowi. Z kolei Lądek-Zdrój i Stronie Śląskie charakteryzują się najbardziej peryferyjnym położeniem i słabą dostępnością komunikacyjną. Stronie Śląskie to gmina posiadająca cenne walory turystyczne, dawniej ukierunkowana na górnictwo (głównie rud uranu), obecnie rozwijająca obok funkcji turystycznej również funkcję przemysłową. Pozostałe gminy sudeckie znalazły się w klasie o średniej konkurencyjności turystycznej. 


\section{Atrakcje turystyczne Sudetów - badanie oferty}

W definicji konkurencyjności regionu turystycznego G.I. Crouch i J.R.B. Ritchie (Mazanec, Wöber i Zins 2007, s. 86-95) wskazują, że jednym z zasadniczych czynników konkurencyjności regionu turystycznego jest zapewnienie gościom satysfakcjonujących i niezapomnianych przeżyć, a kluczowymi zasobami i czynnikami przyciągającymi odwiedzających są ukształtowanie terenu i klimat, kultura i historia, powiązania rynkowe, dostępne aktywności, wydarzenia, rozrywka i infrastruktura turystyczna.

Większość z tych czynników można przypisać do jednej z czerech grup atrakcji turystycznych zaproponowanych przez J. Swarbrooke'a (2002):

- naturalne atrakcje turystyczne, których walory są związane z fizycznymi elementami środowiska naturalnego, np. plaże, góry, jaskinie, jeziora, rzeki, lasy,

- dzieła stworzone przez człowieka, ale w innym celu niż przyciąganie turystów, które z czasem stały się atrakcjami samymi w sobie, np. obiekty prehistoryczne, budynki związane ze znanymi ludźmi, zespoły pałacowo-ogrodowe, ośrodki przemysłowe, budowle sakralne,

- miejsca zaprojektowane i zbudowane od podstaw jako atrakcje, np. parki rozrywki, kasyna, uzdrowiska, parki safari,

- wydarzenia: imprezy kulturalne, sportowe, religijne, festiwale, igrzyska olimpijskie itp. (Kruczek 2017, s. 12-13).

Doświadczenia turystyczne mogą być zdobywane podczas odwiedzania wszystkich typów atrakcji turystycznych znajdujących się w Sudetach.

Od 15 lutego do 15 kwietnia 2018 r. przeprowadzono w gminach o najwyższej i najniższej konkurencyjności turystycznej badanie oferty atrakcji turystycznych. Do tego celu wykorzystano popularną aplikację TripAdvisor. Aplikacja ta pozwoliła na ustalenie lokalizacji obiektów określonych jako atrakcje turystyczne w poszczególnych gminach sudeckich. Ponadto dokonano analizy wpisów, opinii i ocen zamieszczanych przez odwiedzających. Pod uwagę brano atrakcje turystyczne posiadające co najmniej 20 recenzji wpisanych przez turystów nie wcześniej niż w 2017 r. Zestawienie zamieszczono w tabeli 1. Kolejnym etapem badania było osobiste odwiedzenie atrakcji o najwyższych ocenach użytkowników aplikacji (co najmniej 4,5 gwiazdki TripAdvisor) w celu weryfikacji zamieszczanych opinii, szczególnie negatywnych.

W gminach o wysokiej konkurencyjności turystycznej w aplikacji TripAdvisor zarejestrowanych było 136 obiektów określanych jako atrakcje turystyczne, natomiast w gminach o małej konkurencyjności turystycznej zarejestrowano w aplikacji 50 takich obiektów. Atrakcje te miały różną rangę. Były to m.in. wypożyczalnie rowerów i przejażdżki na kucykach, rynki miejscowości i muzea, aż po znaczące atrakcje turystyczne, takie jak zamek Książ, gdzie frekwencja 
była wysoka, czy parki narodowe. Duże zainteresowanie turystów (co najmniej 20 wpisanych recenzji) wzbudzało tylko 67 atrakcji, czyli 36\% zarejestrowanych obiektów. Większość atrakcji turystycznych znajduje się w gminach o największej konkurencyjności turystycznej. Wyjątkami są Kłodzko i Wałbrzych dla większości turystów pełniące funkcję ośrodków rozrządowych i tranzytowych.

Tabela 1. Badane atrakcje turystyczne w Sudetach (stan na 30.04.2018 r.)

\begin{tabular}{|c|c|c|c|}
\hline Miejscowość & $\begin{array}{c}\text { Atrakcje } \\
\text { turystyczne } \\
\text { w TripAdvisor }\end{array}$ & $\begin{array}{l}\text { Atrakcje turystyczne } \\
\text { oceniane najwyżej }\end{array}$ & $\begin{array}{l}\text { Atrakcje turystyczne } \\
\text { oceniane niżej }\end{array}$ \\
\hline Karpacz & 27 & $\begin{array}{l}\text { Śnieżka }(4,5), \text { kościół Wang } \\
(4,5), \text { tory saneczkowe }(4,5), \\
\text { zapora na Łomnicy }(4,5), \\
\text { Muzeum Zabawek }(4,5), \\
\text { Muzeum Klocków Lego }(4,5), \\
\text { Karkonoskie Tajemnice }(4,5), \\
\text { Karkonoski Park Narodowy } \\
(4,5)\end{array}$ & $\begin{array}{l}\text { anomalia grawitacyjna }(4,0) \text {, } \\
\text { Muzeum Sportu i Turystyki } \\
(4,0) \text {, Park Bajek }(4,0), \text { Dziki } \\
\text { Wodospad }(4,0)\end{array}$ \\
\hline $\begin{array}{l}\text { Szklarska } \\
\text { Pręba }\end{array}$ & 11 & $\begin{array}{l}\text { Wysoki Kamieńa }(5,0), \text { Bieg } \\
\text { Piastów }(5,0), \text { Wodospad } \\
\text { Szklarki }(4,5), \text { Wodospad } \\
\text { Kamieńczyka }(4,5)\end{array}$ & $\begin{array}{l}\text { Muzeum Mineralogiczne } \\
(4,0), \text { Leśna Huta }(4,0), \text { skałka } \\
\text { Chybotek }(4,0) \text {, Zakręt Śmierci } \\
(3,5), \text { Dinopark }(3,5)\end{array}$ \\
\hline $\begin{array}{l}\text { Świeradów- } \\
\text {-Zdrój }\end{array}$ & 12 & $\begin{array}{l}\text { single track }(5,0) \text {, kolej gondo- } \\
\text { lowa }(4,5), \text { Stóg Izerskib }(4,5)\end{array}$ & - \\
\hline Kudowa-Zdrój & 28 & $\begin{array}{l}\text { Szczeliniec Wielkic }(5,0), \\
\text { Błędne Skały }(5,0), \text { Park Naro- } \\
\text { dowy Gór Stołowych }(4,5), \\
\text { Park Zdrojowy }(4,5), \text { skansen } \\
\text { w Pstrążnej }(4,5), \text { Ogród } \\
\text { Muzyczny }(4,5)\end{array}$ & $\begin{array}{l}\text { Kaplica Czaszek }(4,0), \\
\text { Muzeum Zabawek „Bajka” } \\
(4,0), \text { Szlak Ginących } \\
\text { Zawodów }(4,0) \text {, ruchoma } \\
\text { szopka }(4,0), \text { aquapark }(3,0)\end{array}$ \\
\hline $\begin{array}{l}\text { Polanica- } \\
\text {-Zdrój }\end{array}$ & 12 & $\begin{array}{l}\text { Park Zdrojowy }(4,5), \text { tor } \\
\text { saneczkowy }(4,5), \text { Park Sza- } \\
\text { chowy }(4,5)\end{array}$ & $\begin{array}{l}\text { pomnik niedźwiedzia }(4,0), \\
\text { Dom Zdrojowy }(4,0)\end{array}$ \\
\hline $\begin{array}{l}\text { Szczawno- } \\
\text {-Zdrój }\end{array}$ & 7 & Park Szwedzki $(4,5)$ & $\begin{array}{l}\text { Park im. Wieniawskiego }(4,0) \text {, } \\
\text { pijalnia wód mineralnych }(4,0)\end{array}$ \\
\hline Jelenia Góra & 11 & $\begin{array}{l}\text { zamek Chojnik }(4,5), \text { Dom } \\
\text { Gerharta i Carla Hauptman- } \\
\text { nów }(4,5), \text { kościół Podwyższe- } \\
\text { nia Krzyża Świętego }(4,5)\end{array}$ & Termy Cieplickie $(4,0)$ \\
\hline $\begin{array}{l}\text { Duszniki- } \\
\text {-Zdrój }\end{array}$ & 9 & $\begin{array}{l}\text { Muzeum Papiernictwa }(4,5) \text {, } \\
\text { Zieleniec - kompleks narciar- } \\
\text { ski }(4,5)\end{array}$ & - \\
\hline Lądek-Zdrój & 8 & - & ratusz $(3,5)$, rynek $(3,5)$ \\
\hline
\end{tabular}


cd. tabeli 1

\begin{tabular}{|c|c|c|c|}
\hline Miejscowość & $\begin{array}{c}\text { Atrakcje } \\
\text { turystyczne } \\
\text { w TripAdvisor }\end{array}$ & $\begin{array}{l}\text { Atrakcje turystyczne } \\
\text { oceniane najwyżej }\end{array}$ & $\begin{array}{l}\text { Atrakcje turystyczne } \\
\text { oceniane niżej }\end{array}$ \\
\hline $\begin{array}{l}\text { Stronie } \\
\text { Śląskie }\end{array}$ & 9 & Jaskinia Niedźwiedzia $(4,5)$ & $\begin{array}{l}\text { Czarna Góra - kompleks } \\
\text { narciarski }(4,0)\end{array}$ \\
\hline Jedlina-Zdrój & 2 & Pałac Jedlinka $(4,5)$ & - \\
\hline $\begin{array}{l}\text { Kamienna } \\
\text { Góra }\end{array}$ & 3 & sztolnie Arado $(4,5)$ & - \\
\hline Lubań & 3 & - & - \\
\hline Bielawa & 10 & - & - \\
\hline Dzierżoniów & 1 & - & - \\
\hline Kłodzko & 11 & $\begin{array}{l}\text { Twierdza Kłodzka }(4,5), \text { most } \\
\text { św. Jana }(4,5) \text {, park miniatur } \\
(4,5)\end{array}$ & $\begin{array}{l}\text { podziemna trasa turystyczna } \\
(4,0) \text {, Stare Miasto }(4,0) \text {, ratusz } \\
(4,0)\end{array}$ \\
\hline Nowa Ruda & 4 & $\begin{array}{l}\text { trasa turystyczna w kopalni } \\
\text { węgla kamiennego }(4,5)\end{array}$ & - \\
\hline Wałbrzych & 18 & $\begin{array}{l}\text { Stara Kopalnia Centrum Nauki } \\
\text { i Sztuki }(4,5)\end{array}$ & $\begin{array}{l}\text { zamek Książ }(4,0) \text {, palmiarnia } \\
(4,0) \text {, zamek Stary Książ }(3,5) \text {, } \\
\text { rynek }(3,5)\end{array}$ \\
\hline
\end{tabular}

a schronisko na Wysokim Kamieniu leży w gminie Stara Kamienica, a Wodospad Szklarki w gminie Piechowice, jednak atrakcje te kojarzone są ze Szklarską Porębą; ${ }^{b}$ schronisko na Stogu Izerskim leży w gminie Mirsk, ale kojarzone jest ze Świeradowem-Zdrojem; ${ }^{c}$ w gminie Radków.

Uwagi: 1) w nawiasie ocena w skali 1-5,2) w rankingu uwzględniono tylko atrakcje turystyczne, które miały co najmniej 20 recenzji.

Źródło: opracowanie własne na podstawie http://www.tripadvisor.com (data dostępu: 15.04.2018).

Z zaprezentowanego w tabeli 1 zestawienia wynika, że w przeważającej większości zainteresowaniem turystów cieszyły się wszystkie typy atrakcji wyróżnione przez J. Swarbrooke'a. Atrakcje naturalne oraz obiekty historyczne związane z regionem otrzymywały nieco wyższe oceny niż atrakcje stworzone sztucznie, bez związku z historią i przyrodą regionu, np. parki bajek, dinozaurów, aquaparki.

Do najczęściej recenzowanych przez użytkowników aplikacji TripAdvisor atrakcji turystycznych w Sudetach należą: kościół Wang w Karpaczu (787 recenzji), zamek Książ w Wałbrzychu (757 recenzji), Wodospad Kamieńczyka w Szklarskiej Porębie (478 recenzji), szczyt Śnieżki w Karpaczu (472 recenzje), Szczeliniec Wielki kojarzony z Kudową-Zdrojem (325 recenzji) i Błędne Skały w Kudowie-Zdroju (317 recenzji). Atrakcje te należą również do najczęściej odwiedzanych na terenie Sudetów. W 2015 r. kościół Wang odwiedziło blisko 200 tys. turystów, zamek Książ 280 tys. turystów (Kruczek 2017, s.166), Wodospad Kamieńczyka 
ok. 260 tys. turystów³ , szczyt Śnieżki ok. 600 tys. turystów, Szczeliniec Wielki 180 tys. turystów (dane za 2014 r.), a Błędne Skały 250 tys. turystów (Rogowski i Małek 2016). Ocenę najpopularniejszych atrakcji turystycznych wyrażającą m.in. doświadczenia z wizyty zaprezentowano w tabeli 2.

Tabela 2. Ocena najpopularniejszych atrakcji turystycznych Sudetów przez użytkowników aplikacji TripAdvisor (stan na 30.04.2018 r.)

\begin{tabular}{|l|c|c|c|c|c|c|}
\hline \multirow{2}{*}{ Atrakcja } & \multirow{2}{*}{ Recenzja } & \multicolumn{5}{|c|}{ Wrażenia } \\
\cline { 3 - 7 } & & doskonałe & $\begin{array}{c}\text { bardzo } \\
\text { dobre }\end{array}$ & średnie & \multirow{2}{*}{ złe } & \multirow{2}{*}{ okropne } \\
\hline \multirow{2}{*}{ Kościół Wang } & $\%$ & 62 & 27 & 9 & 1 & 1 \\
\cline { 2 - 8 } & liczba & 381 & 162 & 65 & 8 & 5 \\
\hline \multirow{2}{*}{ Szczyt Śnieżki } & $\%$ & 74 & 18 & 6 & 1 & 1 \\
\cline { 2 - 8 } & liczba & 274 & 62 & 23 & 6 & 3 \\
\hline Wodospad Kamieńczyka & $\%$ & 60 & 31 & 7 & 2 & 1 \\
\cline { 2 - 8 } & liczba & 234 & 119 & 23 & 2 & 1 \\
\hline Zamek Książ & $\%$ & 53 & 29 & 13 & 4 & 1 \\
\cline { 2 - 8 } & liczba & 285 & 143 & 88 & 27 & 8 \\
\hline Szczeliniec Wielki & $\%$ & 84 & 14 & 2 & 0 & 0 \\
\cline { 2 - 8 } & liczba & 240 & 40 & 7 & 0 & 0 \\
\hline Błędne Skały & $\%$ & 81 & 15 & 4 & 0 & 0 \\
\cline { 2 - 7 } & liczba & 239 & 43 & 11 & 1 & 0 \\
\hline
\end{tabular}

Źródło: opracowanie własne na podstawie: http://www.tripadvisor.com (data dostępu: 15.04.2018).

Większość badanych atrakcji turystycznych ocenianych było bardzo pozytywnie. Opinie były przychylne, zachęcające innych użytkowników aplikacji do przyjazdu, wysoko oceniające doświadczenia i wrażenia podczas odwiedzin atrakcji.

Użytkownicy aplikacji TripAdvisor wpisywali niewiele negatywnych opinii. Głównie dotyczyły one konieczności wnoszenia opłaty za zwiedzanie w przypadku kościoła Wang, nieczynnego schroniska i restauracji na szczycie Śnieżki, zbyt wysokich cen wstępu i skromnego wyposażenia wnętrz w zamku Książ. Negatywnie oceniano także zbyt duży ruch turystyczny w sezonie, co powodowało znaczne niedogodności w zwiedzaniu (kolejki, kłopot z dojazdem, brak miejsc parkingowych). Zdarzały się również opinie typowo malkontenckie, np. że Wodospad Kamieńczyka jest zbyt mały w porównaniu z wodospadem Niagara i nie powinien być określany mianem atrakcji turystycznej.

${ }^{3}$ Wielkości szacunkowe na podstawie danych Karkonoskiego Parku Narodowego, zob. (Wasiuk 2016). 
Biorąc pod uwagę preferencje turystyczne Polaków oraz aktualne trendy w krajowej turystyce, m.in. ciągłe poszukiwanie nowych doznań i emocji, stałą pogoń za nowością, zaskoczeniem, zachwytem, dążenie do ilościowego multiplikowania wrażeń kosztem jakości doznań i przeżyć, typowy dla postmodernizmu kolaż walorów i wrażeń - potrzeba doznawania coraz to nowych i silniejszych bodźców pobudzających emocje (Stasiak 2011), można bez wątpienia stwierdzić, że tworzenie nowych i odpowiednia sprzedaż już istniejących atrakcji turystycznych jest jednym z koniecznych warunków kształtowania konkurencyjności regionów turystycznych. Gminy sudeckie powinny fakt ten uwzględnić. Działania z zakresu podnoszenia konkurencyjności turystycznej powinny mieć charakter kompleksowy i składać się m.in. z następujących działań:

- szeroka promocja sudeckich atrakcji turystycznych wśród turystów i mieszkańców regionu,

- przystosowywanie istniejących walorów przyrodniczych i antropogenicznych oraz infrastruktury (np. zakładów przemysłowych) do obsługi ruchu turystycznego w taki sposób, aby stawały się one atrakcjami w opinii turystów,

- tworzenie nowych atrakcji turystycznych wywołujących pozytywne doświadczenia wśród turystów,

- przy tworzeniu atrakcji turystycznych niezwiązanych z historią i przyrodą regionu dbałość o ich unikatowość, gdyż budowa kolejnego „domu do góry nogami”, następnego parku dinozaurów i muzeum figur woskowych nie jest przez turystów pozytywnie oceniana,

- tworzenie odpowiedniej infrastruktury turystycznej wokół atrakcji,

- wprowadzanie nowych form zwiedzania i poznawania atrakcji turystycznych, np. fabularyzowane zwiedzanie, LARP (live action role-playing), questing, geocaching, nocne zwiedzanie zabytków, tworzenie specjalistycznych programów wycieczek (przyrodniczych, geologicznych, historycznych),

- rozwijanie nowych form turystyki dostarczających ponadprzeciętnych emocji, np. wykorzystywanie warunków klimatycznych do lotów szybowcowych,

- organizowanie wydarzeń mogących stać się wizerunkową atrakcją turystyczną regionu.

Wszystkie te działania poprzez kreowanie ponadprzeciętnych doświadczeń mogą przyczynić się do podniesienia konkurencyjności turystycznej regionu.

\section{Zakończenie}

Różnego rodzaju atrakcje turystyczne w dobie ekonomii doświadczeń mogą i powinny być jednym z wyróżników konkurencyjności regionu turystycznego. W przypadku Sudetów jest to nieco utrudnione, ponieważ tradycje kulturowe 
zostały przerwane na tym terenie po II wojnie światowej. Proces ich odtworzenia oraz wykształcenia nowych tradycji wymaga wiele czasu oraz nakładów sił i środków. Chociaż brak powszechnie znanych i kultywowanych obyczajów i elementów folkloru nie sprzyja rozwojowi niektórych form turystyki, to ogromne bogactwo walorów przyrodniczych oraz elementów kultury materialnej (np. zabytki) daje regionowi sudeckiemu przewagę konkurencyjną nad innymi regionami turystycznymi w kraju. Taki stan rzeczy sprzyja również tworzeniu sztucznych atrakcji turystycznych będących swoistego rodzaju „pułapkami turystycznymi”, co może wśród turystów wywoływać doświadczenia negatywne.

Odnosząc się do postawionej we wstępie hipotezy, można jednoznacznie stwierdzić, że atrakcje turystyczne mogą być skutecznie wykorzystywane do kreowania unikalnych doświadczeń turystów i tym samym poprawiania konkurencyjności regionu na co najmniej krajowym rynku turystycznym. Wskazują na to zaprezentowane w artykule ogólnopolskie trendy rynkowe i zachowania turystyczne Polaków.

Przedstawione w artykule wyniki badań mają też pewne ograniczenia, ponieważ przeprowadzono je na podstawie opinii zamieszczanych tylko w jednym portalu społecznościowym, tj. TripAdvisor. Pominięto inne media internetowe (np. Google Maps), nie przeprowadzono również bezpośrednich badań ankietowych w atrakcjach turystycznych. Badania te będą jednak kontunuowane.

\section{Literatura}

Cohen E. (2011), Zmieniajqce się oblicza wspótczesnej turystyki, „Folia Turistica”, vol. 25, nr 2.

Crouch G.I., Ritchie J.R.B. (1999), Tourism, Competitiveness, and Societal Prosperity, „Journal of Business Research”, vol. 44, https://doi.org/10.1016/s0148-2963(97)00196-3.

Dwyer L., Kim C. (2003), Destination Competitiveness: Determinants and Indicators, „Current Issues in Tourism”, vol. 6, nr 5, https://doi.org/10.1080/13683500308667962.

Dziewianowska K. (2013), Nowe oblicze marketingu - koncepcja marketingu doświadczén, „Marketing i Rynek”, nr 1.

Gryszel P. (2014a), Konkurencieschopnost' regionov cestovneho ruchu - metody merania, „Ekonomická Revue Cestovného Ruchu”, vol. 47, nr 2.

Gryszel P. (2014b), Ocena konkurencyjności górskich gmin turystycznych z wykorzystaniem metody taksonomicznej, „Folia Turistica”, nr 32.

Gryszel P. (2014c), The Assessment of Tourist Destinations Competitiveness Using a Synthetic Measure (w:) Management 2014, Business, Management and Social Sciences Research, R. Štefko, M. Frankovský, J. Vravec (eds), Prešovska univerzita v Prešove, Prešov.

Gryszel P. (2015), Methods for the Assessment of Tourist Destinations, „Zeszyty Naukowe Uniwersytetu Szczecińskiego. Service Management”, vol. 15, nr 1, https://doi. org/10.18276/smt.2015.15-05. 
Gryszel P., Walesiak M. (2018), The Application of Selected Multivariate Statistical Methods for the Evaluation of Tourism Competitiveness of The Sudety Communes, „Argumenta Oeconomica”, vol. 40, nr 1.

Iwasiński Ł. (2015), Turystyka jako rynek doświadczeń, „Kultura Popularna”, vol. 44, nr 2. Jędrusik M., Makowski J., Plit F. (2010), Geografia turystyczna świata. Nowe trendy. Regiony turystyczne, Wydawnictwo Uniwersytetu Warszawskiego, Warszawa.

Kaczmarek J., Stasiak A., Włodarczyk B. (2010), Produkt turytsyczny. Pomyst. Organizacja. Zarzqdzanie, PWE, Warszawa.

Konkurencyjność regionalna. Koncepcje - strategie - przykłady (2012), red. E. Łaźniewska, M. Gorynia, Wydawnictwo Naukowe PWN, Warszawa.

Kowalczyk A. (2000), Geografia turyzmu, Wydawnictwo Naukowe PWN, Warszawa.

Kowalczyk A. (2014), Od turystyki $3 S$ do turystki 3E. Czy to zmiana paradygmatu turystyki masowej? (w:) Turystyka wobec zmian współczesnego świata. Zmiany, bariery, innowacje, red. G. Gołembski, A. Niezgoda, Wydawnictwo Uniwersytetu Ekonomicznego w Poznaniu, Poznań.

Kruczek Z. (2011), Atrakcje turystyczne. Fenomen, typologia, metody badań, Proksenia, Kraków.

Kruczek Z. (2017), Frekwencja w polskich atrakcjach turystycznych 2011-2015, Proksenia, Kraków.

Lijewski T. Mikułowski B., Wyrzykowski J. (2002), Geografia turystyki Polski, PWE, Warszawa.

Łaźniewska E. (2013), Konkurencyjność regionalna w czasie i przestrzeni na przykładzie polskich regionów, Wydawnictwo Uniwersytetu Ekonomicznego w Poznaniu, Poznań.

MacCannell D. (2005), Turysta. Nowa teoria klasy próżniaczej, Muza SA, Warszawa.

Majchrzak M. (2014), Ekonomia doświadczeń a przewaga konkurencyjna przedsiębiorstwa, „Kwartalnik Nauk o Przedsiębiorstwie”, nr 1.

Marciszewska B. (2010), Produkt turystyczny a ekonomia doświadczeń, C.H. Beck, Warszawa.

Mazanec J.A. , Wöber K., Zins A.H. (2007), Tourism Destination Competitiveness: From Definition to Explanation?, ,Journal of Travel Research”, vol. 46, nr 1, https://doi. org/10.1177/0047287507302389.

Middleton V.T.C. (1996), Marketing w turystyce, Polska Agencja Promocji Turystyki, Warszawa.

Nowacki M. (2012), Atrakcje turystyczne: koncepcje, stan, determinant zadowolenia osób zwiedzajacych, Akademia Wychowania Fizycznego w Poznaniu, Poznań.

Pine J., Gilmore J. (1998), Welcome to the Experience Economy, „Harvard Business Review”, nr 7-8.

Podemski K. (2004), Socjologia podróży, Wydawnictwo Naukowe UAM, Poznań.

Ritchie J., Crouch G. (2005), The Competitive Destination: A Sustainable Tourism Perspective, CABI, London.

Rogowski M., Małek B. (2016), Monitoring ruchu turystycznego w Parku Narodowym Gór Stołowych - założenia projektu i wstępne wyniki badań (w:) Uwarunkowania i plany rozwoju turystyki. Turystyka przyrodnicza i uwarunkowania jej rozwoju, red. Z. Młynarczyk, A. Zajadacz, Turystyka i Rekreacja - Studia i Prace nr 18, Bogucki Wydawnictwo Naukowe, Poznań. 
Stasiak A. (2011), Turystyka rodzinna w świecie ponowoczesnym (w:) Turystyka rodzinna a zachowania prospołeczne, red. J. Śledzińska, B. Włodarczyk, Wydawnictwo PTTK Kraj, Warszawa.

Stasiak A. (2013a), Nowe przestrzenie i formy turystyki w gospodarce doświadczeń, „Turyzm”, nr 23/2.

Stasiak A. (2013b), Produkt turystyczny w gospodarce doświadczeń, ,Turyzm”, nr 23/1.

Swarbrooke J. (2002), Development and Management of Visitor Attractions, Butterworth-Heinemann, Oxford.

Šmardová L. (2012), Konkurencieschopnost' ciel'ového miesta (w:) Manažment ciel'ového miesta cestovného ruchu, red. M. Gůčik, Slovak-Swizz Tourism, Banská Bystrica.

Walesiak M. (2011), Uogólniona miara odległości GDM w statystycznej analizie wielowymiarowej z wykorzystaniem programu $R$, Wydawnictwo Uniwersytetu Ekonomicznego we Wrocławiu, Wrocław.

Wasiuk A. (2016), Ruch turystyczny w Karkonoskim Parku Narodowym w latach 2010_ 2016, „Karkonosze. Czasopismo Sudetów Zachodnich”, nr 4(286).

Żemła M. (2017), Rola koncepcji ekonomii doświadczeń w postmodernistycznej interpretacji trendów rynkowych w turystyce i budowie nowoczesnych produktów turystycznych, Prace Komisji Geografii Przemysłu Polskiego Towarzystwa Geograficznego, vol. 31, nr 3, https://doi.org/10.24917/20801653.313.1.

\section{The Experience Economy in Shaping the Competitiveness of Tourist Regions}

(Abstract)

Contemporary tourist attractions that McDonaldsize and Disneyize the product they offer tourists are very well-received and are often the main reason tourist trips are taken. Thus, they significantly boost the competitiveness of their regions' tourism. Based on an examination of the subject literature and surveys of tourists visiting the Sudety Mountain as a tourist region, the article assesses the impact of contemporary tourist attractions, creating the experience of tourists, on the competitiveness of the tourist region. The analysis included entries, evaluations and statements expressed in TripAdvisor's app, and referring to tourist attractions located in the tourist region studied. The contemporary approach associated with the experience economy is one of the most effective tools for creating the competitive position of the Sudety tourist market.

Keywords: competitiveness, tourist region, experience economy, tourist attraction. 